\title{
Influence of the period of year on the chemical composition and digestibility of pasture and fodder selected by goats in caatinga
}

\section{Influência da época do ano na composição química e digestibilidade do pasto e da forragem selecionados por caprinos na caatinga}

\author{
SILVA, Messias José dos Santos ${ }^{1 *}$; SILVA, Dulciene Karla de Andrade ${ }^{1}$; \\ MAGALHÃES, André Luiz Rodrigues ${ }^{1}$; PEREIRA, Kedes Paulo ${ }^{2}$; SILVA, Érica Carla \\ Lopes da ${ }^{1}$; CORDEIRO, Fábia Simone Bezerra ${ }^{1}$; NORONHA, Claudia Tenório de ${ }^{1}$; \\ SANTOS, Kelly Cristina dos ${ }^{3}$
}

\footnotetext{
${ }^{1}$ Universidade Federal Rural de Pernambuco, Departamento de Zootecnia, Garanhuns, Pernambuco, Brasil.

${ }^{2}$ Universidade Federal de Alagoas, Centro de Ciências Agrárias, Maceió, Alagoas, Brasil.

${ }^{3}$ Universidade Federal Rural de Pernambuco, Departamento de Zootecnia, Recife, Pernambuco, Brasil.

*Endereço para correspondência: messiaszootecnia@hotmail.com
}

\section{SUMMARY}

This study aimed to verify the influence of months on chemical composition and in vitro digestibility of pasture and forage selected by goats in the semiarid region of Brazil's Pernambuco state. Six male goats fistulated in the rumen were used in a completely randomized design. Forage collection was conducted in herbaceous and shrub/tree layers, in order to simulate goat grazing, and materials were separated into leaves and branches. Extrusa and pasture collections were held in November, January and February/March. There was collection month $(\mathrm{P}<0.05)$ effect for pasture on dry matter (DM), crude protein $(\mathrm{CP})$, neutral detergent fiber (NDF), acid detergent fiber (ADF), with average values of $458.27 \mathrm{~g} / \mathrm{kg}$ $\mathrm{NM}$ and $155.46,521.30$ and $390.13 \mathrm{~g} / \mathrm{kg} \mathrm{DM}$, respectively. For the stem $(\mathrm{P}<0.05)$ for $\mathrm{DM}$, Organic matter (OM), mineral matter (MM), ethereal stratum (EE), ADF, acid detergent unavailable protein (AIP), total carbohydrates (TCHO) and dry matter in vitro digestibility (DMIVD), with average values of $487.47 \mathrm{~g} / \mathrm{kg}$ $\mathrm{NM}$ and 930.80, 69.07, 20.67, 440.30 and $63.78 \mathrm{~g} / \mathrm{kg} \mathrm{DM}$, respectively. About the extrusa, there was collection time effect $(\mathrm{P}<0.05)$ on the DM, OM, MM, CP, EE, AIP, TCHO, Nonfibrous carbohydrates (NFC) and DMIVD, with average values of $84.53 \mathrm{~g} / \mathrm{kg} \mathrm{DM}, 863.03$, 136.97, 152.90, 33.60, 14.07, 676.37 and $55.35 \mathrm{~g} / \mathrm{kg} \mathrm{DM}$, respectively. Rainfall changes in the rainy season in the caatinga altered pasture quality, causing changes in the diet selected by goats, mainly in DM, CP, CNF and DMIVD.

Keywords: food, extrusa, native pasture, semiarid region

\section{RESUMO}

Objetivou-se verificar a influência dos meses do ano sobre a composição química e digestibilidade in vitro do pasto e da forragem selecionada por caprinos no semiárido pernambucano. Foram utilizados seis caprinos machos fistulados no rúmen, distribuídos em delineamento inteiramente casualizado. As coletas de forragem foram realizadas nos estratos herbáceo e arbustivo/arbóreo, simulando o pastejo dos caprinos, e os materiais separados em folhas e galhos. As coletas da extrusa e do pasto foram realizadas nos meses de novembro, janeiro e fevereiro/março. Houve efeito do mês de coleta $(\mathrm{P}<0,05)$, para a folha do pasto sobre a matéria seca (MS), proteína bruta (PB), fibra em detergente neutro (FDN), fibra em detergente ácido (FDA), com valores médios de $\quad 458,27 \mathrm{~g} / \mathrm{Kg} \quad \mathrm{MN} ; \quad 155,46 ; \quad 521,30$; $390,13 \mathrm{~g} / \mathrm{Kg}$ MS respectivamente. Para o caule $(\mathrm{P}<0,05)$ sobre $\mathrm{MS}$, matéria orgânica $(\mathrm{MO})$, matéria mineral $(\mathrm{MM})$, estrato etéreo $(\mathrm{EE})$, FDA, proteína indisponível em detergente ácido (PIDA), carboidratos totais (CHOT), 
digestibilidade in vitro da matéria seca (DIVMS), com valores médios de $487,47 \mathrm{~g} / \mathrm{Kg}$ MN; 930,80;69,07;20,67;440,30;63,78g/Kg MS respectivamente. Sobre a extrusa, ocorreu efeito do mês de coleta $(\mathrm{P}<0,05)$ sobre a MS, MO, MM, PB, EE, PIDA, CHOT, carboidratos não fibrosos (CNF) e DIVMS, com valores médios de 84,53g/Kg MS; 863,03; 136,97; 152,$90 ; 33,60 ; 14,07 ; 676,37 ; 55,35 \mathrm{~g} / \mathrm{Kg} \mathrm{MS}$ respectivamente. Alterações na pluviosidade nos meses chuvosos na caatinga alteraram a qualidade da pastagem, ocasionando mudanças na dieta selecionada pelos caprinos, principalmente na MS, PB, CNF e DIVMS.

Palavras-chaves: alimentação, extrusa, pastagem nativa, semiárido

\section{INTRODUCTION}

The Brazilian semiarid region is characterized by high temperatures, high evaporation rate and marked irregularity in rainfall distribution (both in time and space), with long drought periods (FERREIRA et al., 2009). These factors make livestock vulnerable to forage resource seasonality.

The Caatinga, native vegetation of this region, has three distinct strata: arboreal, shrub and herbaceous, with predominance of deciduous plants that lose their leaves the dry season beginning, and many have thorns.

In the rainy season, the herbaceous layer resurrects in the Caatinga, which features a variety of naturalized native and exotic plants. Among plants, about $10 \%$ may have forage characteristics, which can be exploited by animals through direct grazing (SOUZA et al., 2013). However, at dry season, woody species leaves begin to compose most of animals' diet, reaching $80 \%$ in ruminants.

Many forage species available in the caatinga, Pernambuca, has high protein content, but low digestibility (Moreira et al., 2006). Although protein amount may be enough to meet animal nutritional requirements during the rainy season, it does not mean that the protein will be available to ruminal microorganisms, as it may have a large indigestible fraction.

Ruminant diet chemical composition in Caatinga varies widely depending on rainfall and botanical composition. The diet selected by grazing animals has different chemical and botanical characteristics compared to the forage available in pasture. More leaves and green materials are selected by animals in relation to stems and dead material (YDOYAGA SANTANA et al., 2011). Therefore, information on animal dry matter intake in different Caatinga grazing systems is still scarce, especially when is handled in several different ways (FORMIGA et al., 2011). For Araújo Filho \& Crispim (2002), native forage digestibility determined for goats and sheep, both in vivo, in vitro or in situ, are generally average. However, animal grazing performance indicates higher values due to selection during grazing, which is conducted by sheep and especially goats. Shrub and tree forages generally have lower digestibility coefficients than those found for herbaceous plants (SANTOS et al. 2009). Probably due to high lignin concentrations and secondary compounds found in these layers.

This study aimed to investigate sampling month influence on chemical composition and in vitro digestibility of pasture (leaves and stems) and forage selected by goats in Pernambuco.

\section{MATERIAL AND MÉTHODS}

The experiment was carried out from November 2010 to March 2011 at the Goat-sheep Farming Training Center, 
Agronomic Institute of Pernambuco IPA - municipality of Sertânia - PE. In (Figure 1), it is possible to observe the amount of rains occurred during January 2010 to March 2011. All procedures were approved by the Ethics Committee on Animal Use-CEUA, Rural Federal University of Pernambuco - UFRPE. Six castrated male goats with undefined breed standard (UBS), fistulated in the rumen and with average body weight (BW) of $25 \mathrm{~kg}$ were used, which received dietary supplementation with mineral mixture ad libitum. Animals were pretreated against endoparasites and ectoparasites and underwent an environment adaptation and management period for 15 days. The experimental period lasted 105 days. Animals were kept in a continuous grazing system in a 37 ha caatinga area.

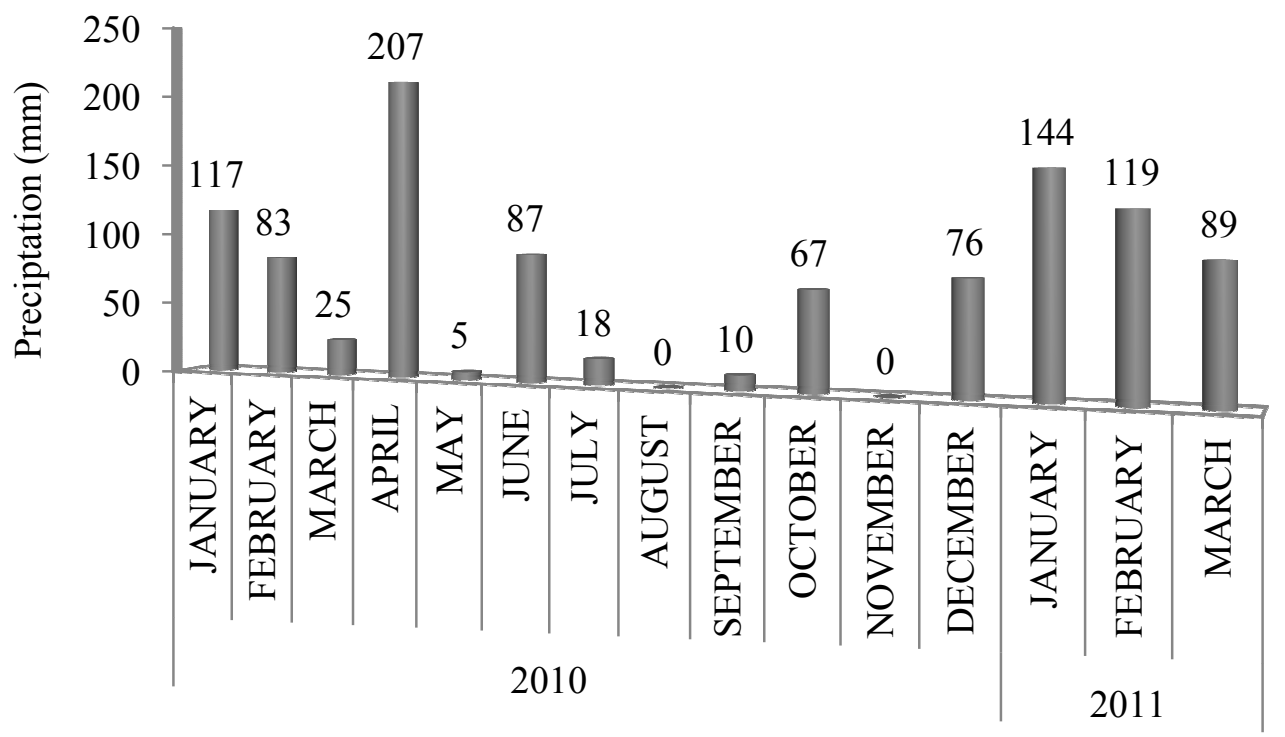

Figure 1. Preciptationl (mm) observed from January 2010 to March 2011 at Sertânia Experimental Station - PE. The experiment occurred from November 2010 to March 2011

Three grazing collections (caatinga) were conducted. The first one took place from 15 to 17 November 2010, the second from 10 to 12 January 2011 , and the third from 28 February to 03 March 2011. On each occasion, herbaceous and shrub/tree layer samples were collected to simulate goat grazing. Subsequently, samples were separated into leaves and stem (only the thinnest branches were collected). The area was divided into seven parallel transects. Extrusa collections were also held in three periods. The first collection took place from 17 to 23 November 2010, the second from 12 to 18 January 2011 and the third from February 24 to March 2, 2011.

Extrusa samples were obtained by ruminal emptying and divided between morning (8:00 a.m.) and afternoon (2:00 p.m.) shifts, in alternate days, in order to reduce ruminal emptying effect on animal grazing activity (feeding behavior) (SANTOS et al., 2009). In samples taken in the morning, animals fasted for 12 hours before having access to pasture. All the initial ruminal 
contents were removed and stored in buckets, regardless of the time of collection, properly identified according to the animals to be returned after the extrudate collection. Subsequently, animals were released in the experimental area for 40 to 60 minutes. After this period, animals were taken and extrusa samples were collected. Samples were identified by animal, period and collection time and were stored for further analysis. Animal ruminal content was returned to the rumen after extrusa collection. In afternoon collections, animals were taken from the pasture immediately prior to collection, prepared as described above, and released in the experimental area.

After pasture and extrusa collection, they were predried in a forced ventilation oven at $55{ }^{\circ} \mathrm{C}$ and grounded in a Willy mill, $1 \mathrm{~mm}$ type. Dry matter (DM) content was determined by drying at 105 ${ }^{\circ} \mathrm{C}$ for 24 hours (AOAC, 1995/ 930.15). Mineral matter (MM) and organic matter (OM) were obtained after sample burning at $600{ }^{\circ} \mathrm{C}$ for 3 hours (AOAC, 1990/942.05). Nitrogen content was determined by Kjeldahl method (AOAC, 1995/954.01), and crude protein content was calculated by $6.25^{\mathrm{x}} \mathrm{N}$ factor. The ether extract was determined by extraction in ethyl ether in the ANKOM $\mathrm{XT}^{10}$ extractor (ANKOM Technology Corporation, Macedon, NY, USA). For neutral detergent fiber (NDF) and acid detergent fiber (ADF) determination, the method described by Van Soest et al. (1991) was used through a Tecnal fiber analyzer, TE-149 model. Neutral detergent (NDIP) and acid (AIP) insoluble nitrogen contents were estimated in residues obtained from NDF and ADF through micro-Kjeldahl method. In order estimate total carbohydrates (TCHO), the equation proposed by Sniffen et al. (1992) was used, while non-fibrous carbohydrates
(NFC) were estimated according to Mertens (1997). DM in vitro digestibility (DMIVD) was obtained according to the methodology described by Tilley and Terry (1963), following modifications described by Holden (1999), with use of Daisy II equipment (ANKOM technology).

It was used the completely randomized design in a factorial arrangement $(2 \times 3)$, (two strata (herbaceous and shrub/arboreal)) and three periods (November, January and February/March) for pasture. For extrudate evaluation, the completely randomized design was used $(6 \times 3),(6$ animals x 3 periods (November, January and February / March)). Analysis of variance and mean comparison were conducted using the Tukey test at 5\% probability. Data were analyzed using the SAEG (UFV, 20070 statistical program.

\section{RESULTS AND DISCUSSION}

There was collection month effect $(\mathrm{P}<0.05)$ for $\mathrm{DM}, \mathrm{CP}, \mathrm{NDF}$ and $\mathrm{ADF}$ in pasture leaves (Table 1). In the case of stems, there was also collection month effect $(\mathrm{P}<0.05)$ for $\mathrm{DM}$, organic matter $(\mathrm{OM})$, mineral matter (MM), EE, ADF, NDIP, total carbohydrates (TCHO) and DMIVD.

DM declined for leaves and stems in the months of February / March due to increased rainfall observed during this collection period, because of the increase in CP and NDF in the leaves between January and February / March. 
Table 1. Pasture chemical composition and in vitro digestibility (leaves and stems) in relation to collection month in Caatinga

\begin{tabular}{|c|c|c|c|c|c|c|c|}
\hline Composition & Part of plant & November of 2010 & January of 2011 & February / March of 2011 & Average & $\mathrm{CV}$ & Meaningfulness \\
\hline \multirow{2}{*}{ Dry matter $(\mathrm{DM})^{1}$} & Leaves & $533.20^{\mathrm{a}}$ & $533.50^{\mathrm{a}}$ & $308.10^{\mathrm{b}}$ & 458.67 & 9.99 & 0.00000 \\
\hline & Stems & $531.50^{\mathrm{a}}$ & $545.80^{\mathrm{a}}$ & $385.10^{\mathrm{b}}$ & 487.47 & 12.89 & 0.00000 \\
\hline \multirow{2}{*}{ Organic matter $(\mathrm{OM})^{2}$} & Leaves & 912.20 & 897.00 & 904.60 & 904.60 & 1.48 & 0.05436 \\
\hline & Stems & $935.40^{\mathrm{a}}$ & $920.90^{\mathrm{b}}$ & $936.10^{\mathrm{a}}$ & 930.80 & 1.29 & 0.01307 \\
\hline \multirow{2}{*}{ Mineral matter $(\mathrm{MM})^{2}$} & Leaves & 87.80 & 103.00 & 95.40 & 95.40 & 14.00 & 0.05436 \\
\hline & Stems & $64.60^{\mathrm{b}}$ & $79.20^{\mathrm{a}}$ & $63.40^{\mathrm{b}}$ & 69.07 & 17.36 & 0.01307 \\
\hline \multirow{2}{*}{ Crude protein $(\mathrm{CP})^{2}$} & Leaves & $166.20^{\mathrm{ab}}$ & $130.20^{\mathrm{b}}$ & $170.00^{\mathrm{a}}$ & 155.47 & 21.62 & 0.02472 \\
\hline & Stems & 71.40 & 98.40 & 80.90 & 83.57 & 28.29 & 0.05006 \\
\hline \multirow{2}{*}{ Ether extract $(\mathrm{EE})^{2}$} & Leaves & 39.30 & 39.80 & 34.30 & 37.80 & 32.18 & 0.31606 \\
\hline & Stems & $25.80^{\mathrm{a}}$ & $19.90^{\mathrm{ab}}$ & $16.30^{\mathrm{b}}$ & 20.67 & 26.58 & 0.00194 \\
\hline \multirow{2}{*}{ Neutral detergent fiber (NDF) ${ }^{2}$} & Leaves & $529.00^{\mathrm{ab}}$ & $487.90^{\mathrm{b}}$ & $547.00^{\mathrm{a}}$ & 521.30 & 9.13 & 0.02941 \\
\hline & Stems & 647.30 & 653.60 & 726.01 & 675.63 & 15.27 & 0.18490 \\
\hline \multirow{2}{*}{ Acid detergent fiber $(\mathrm{ADF})^{2}$} & Leaves & $380.20^{\mathrm{ab}}$ & $316.10 b$ & $474.10^{\mathrm{a}}$ & 390.13 & 29.49 & 0.01716 \\
\hline & Stems & $403.50^{\mathrm{ab}}$ & $392.00^{\mathrm{b}}$ & $525.40^{\mathrm{a}}$ & 440.30 & 27.00 & 0.03377 \\
\hline \multirow{2}{*}{ Insoluble protein in neutral detergent (NDIP) ${ }^{3}$} & Leaves & 853.80 & 884.20 & 844.20 & 860.73 & 24.07 & $* * * * * * *$ \\
\hline & Stems & 643.70 & 478.60 & 605.10 & 575.80 & 37.17 & 0.21558 \\
\hline \multirow{2}{*}{ insoluble protein in acid detergent (AIP) ${ }^{3}$} & Leaves & 569.00 & 824.10 & 622.20 & 671.77 & 42.70 & 0.13020 \\
\hline & Stems & $831.50^{\mathrm{a}}$ & $670.90^{\mathrm{a}}$ & $410.90^{b}$ & 637.77 & 35.14 & $* * * * * * *$ \\
\hline \multirow{2}{*}{ Total carbohydrates $(\mathrm{TCHO})^{2}$} & Leaves & 706.70 & 695.20 & 700.30 & 700.73 & 4.79 & $* * * * * * *$ \\
\hline & Stems & $838.20^{\mathrm{a}}$ & $803.70^{b}$ & $839.10^{\mathrm{a}}$ & 827.00 & 3.64 & 0.01173 \\
\hline \multirow{2}{*}{ Non-fiber carbohydrates (NFC) ${ }^{2}$} & Leaves & 177.70 & 207.30 & 153.30 & 179.43 & 32.44 & 0.13548 \\
\hline & Stems & 190.90 & 149.00 & 113.00 & 150.97 & 66.65 & 0.24162 \\
\hline \multirow{2}{*}{ DM in vitro digestibility (DMIVD) $)^{2}$} & Leaves & 647.50 & 670.10 & 669.30 & 662.30 & 7.96 & $* * * * * * *$ \\
\hline & Stems & $439.80^{\mathrm{b}}$ & $499.20^{\mathrm{a}}$ & $437.40^{\mathrm{b}}$ & 458.80 & 10.04 & 0.00846 \\
\hline
\end{tabular}

${ }^{1}\left(\mathrm{~g} \mathrm{~kg}^{-1}\right)$ natural of matter; ${ }^{2} \mathrm{~kg}^{-1} \mathrm{DM} ;{ }^{3} \mathrm{~g} \mathrm{~kg}^{-1} \mathrm{CP}$; Followed by means the same letter on the line do not differ by Tukey test (P>0.05). 
For stem, there was increased FDA, TCHO, and reduced PIDA, observed for collections carried out in the same months of collection. These differences are probably due to the rains during the last two months of evaluation (Figure 1 ), contributing to plants regrowth and consequently increasing the availability of youngest phytomass, altering the grass' chemical composition.

$\mathrm{CP}$ values were higher in leaves, as expected, since leaves have higher cellular content in relation to stems, with values of 155.5 and $83.6 \mathrm{~g} / \mathrm{kg} \mathrm{DM}$ for leaves and stems, respectively. Leaf and steam average NDF levels were 521.3 and $765.7 \mathrm{~g} / \mathrm{kg} \mathrm{DM}$, respectively. These values were higher for stems and lower for leaves than values found by Santos et al. (2009), who observed average NDF content of $593.9 \mathrm{~g} / \mathrm{kg} \mathrm{DM}$ while studying the diet of fistulated sheep in a Caatinga area, in the same location and assessment period. Stems have high NDF content, as they have higher structural carbohydrate amount in relation to leaves, increasing pasture NDF and ADF amount.

Average NDIP value was 86.07 for leaves and $575.8 \mathrm{~g} / \mathrm{kg} \mathrm{CP}$ for stems. Results found in this study were higher than those found by Moreira et al. (2006) and Ydoyaga Santana et al. (2011), evaluating the rainy period, for leaves and similar for stems. AIP averaged $671.7 \mathrm{~g} / \mathrm{kg} \mathrm{CP}$ for leaves and $637.7 \mathrm{~g} / \mathrm{Kg} \mathrm{CP}$ for stems, reflecting Caatinga nutritional reality as a forage source. Although there is high protein content, a large fraction is complexed with lignin, making it unavailable to the animal.

Collection months influenced $(\mathrm{P}<0.05)$ leaf DM, AIP and DMIVD and stem DM, OM, MM, NDF, ADF, NDIP, AIP, NFC and DMIVD of herbaceous layer (Table 2).
Leaf and stem average $\mathrm{CP}$ contents were 162.5 and $77.2 \mathrm{~g} / \mathrm{kg} \mathrm{DM}$, respectively, which were considered high for a pasture formed by caatinga. CP levels found in this study are above the minimum requirement of $70 \mathrm{~g} / \mathrm{kg}$ DM recommended by Van Soest (1994) to keep a proper ruminal environment for microbial growth and maintenance.

The high CP content observed in this experiment is due to the high leaf: stem ratio in the pasture, caused by precipitation during the experimental period. Formiga et al. (2011) assessed a Caatinga herbaceous layer enriched with buffelgrass and grazed by sheep and goats, in the dry period, in which a $\mathrm{CP}$ value of $33 \mathrm{~g} / \mathrm{kg}$ DM was found. The authors attributed the low CP content to a leaf/stem ratio reduction in the pasture and to plant fruiting and senescence approximation, which was associated to enrichment by low-protein grass.

Caatinga $\mathrm{CP}$ amount is usually not a limiting factor for animals, especially during the rainy season, as their diet consists of different forage species. However, possible high levels of secondary compounds, such as tannins, significant lignin amount and forage low digestibility, along with high AIP percentage, can make $\mathrm{CP}$ a limiting factor for animal performance, even in rainy seasons.

Regarding the shrub/tree layer, DM values only varied $(\mathrm{P}<0.05)$ in the last collection month for leaves and stems (Table 3). On average, leaf and stem DM contents were 470.9 and $501.6 \mathrm{~g} / \mathrm{kg}$ $\mathrm{DM}$, respectively. Results found in this study were higher than those found by Drumond et al. (2007), 232.5 and 459.3 $\mathrm{g} / \mathrm{kg} \mathrm{DM}$ for leaves and branches, respectively, while studying Cnidoscolus phyllacanthus (Muell. Arg.). 
Table 2. Herbaceous layer (leaves and stems) chemical composition and in vitro digestibility in relation to collection month

\begin{tabular}{|c|c|c|c|c|c|c|c|}
\hline Composition & Part of plant & November of 2010 & January of 2011 & February / March of 2011 & Average & $\mathrm{CV}$ & Meaningfulness \\
\hline \multirow{2}{*}{ Dry matter $(\mathrm{DM})^{1}$} & Leaves & $520.60^{\mathrm{a}}$ & $502.30^{\mathrm{a}}$ & $313.80^{b}$ & 445.57 & 11.14 & 0.00004 \\
\hline & Stems & $522.50^{\mathrm{a}}$ & $528.20^{\mathrm{a}}$ & $369.50^{\mathrm{b}}$ & 473.40 & 16.82 & 0.01290 \\
\hline \multirow{2}{*}{ Organic matter $(\mathrm{OM})^{2}$} & Leaves & 914.90 & 893.90 & 910.10 & 906.30 & 1.64 & 0.10410 \\
\hline & Stems & $927.20^{\mathrm{ab}}$ & $908.70^{\mathrm{b}}$ & $937.00^{\mathrm{a}}$ & 924.30 & 1.56 & 0.02647 \\
\hline \multirow{2}{*}{ Mineral matter $(\mathrm{MM})^{2}$} & Leaves & 85.10 & 106.10 & 89.90 & 93.70 & 15.82 & 0.10410 \\
\hline & Stems & $72.80^{\mathrm{ab}}$ & $91.30^{\mathrm{a}}$ & $63.00^{\mathrm{b}}$ & 75.70 & 18.95 & 0.02647 \\
\hline \multirow{2}{*}{ Crude protein $(\mathrm{CP})^{2}$} & Leaves & 160.40 & 152.60 & 174.60 & 162.53 & 20.88 & $* * * * * * *$ \\
\hline & Stems & 69.80 & 89.10 & 72.80 & 77.23 & 21.48 & 0.18230 \\
\hline \multirow{2}{*}{ Ether extract $(\mathrm{EE})^{2}$} & Leaves & 46.90 & 41.70 & 33.70 & 40.77 & 27.17 & 0.20427 \\
\hline & Stems & 24.10 & 19.80 & 16.60 & 20.17 & 25.17 & 0.10209 \\
\hline \multirow{2}{*}{ Neutral detergent fiber (NDF) ${ }^{2}$} & Leaves & 547.10 & 563.20 & 571.40 & 560.57 & 8.77 & $* * * * * * *$ \\
\hline & Stems & $520.30^{\mathrm{b}}$ & $648.90^{\mathrm{ab}}$ & $734.20^{\mathrm{a}}$ & 634.47 & 15.32 & 0.01331 \\
\hline \multirow{2}{*}{ Acid detergent fiber $(\mathrm{ADF})^{2}$} & Leaves & 384.20 & 222.10 & 360.70 & 322.33 & 41.07 & 0.15484 \\
\hline & Stems & $600.40^{\mathrm{a}}$ & $380.80^{\mathrm{b}}$ & $587.70^{\mathrm{a}}$ & 522.97 & 31.11 & 0.00337 \\
\hline \multirow{2}{*}{ Insoluble protein in neutral detergent (NDIP) ${ }^{3}$} & Leaves & 783.10 & 922.40 & 754.50 & 820.00 & 31.11 & $* * * * * * *$ \\
\hline & Stems & $493.90^{\mathrm{ab}}$ & $391.10^{b}$ & $652.40^{\mathrm{a}}$ & 512.47 & 24.46 & 0.02000 \\
\hline \multirow{2}{*}{ insoluble protein in acid detergent (AIP) ${ }^{3}$} & Leaves & $222.4^{\mathrm{b}}$ & $906.40^{\mathrm{a}}$ & $470.70^{\mathrm{b}}$ & 533.17 & 39.82 & 0.00090 \\
\hline & Stems & $797.20^{\mathrm{a}}$ & $298.50^{b}$ & $665.50^{\mathrm{a}}$ & 587.07 & 31.40 & 0.00296 \\
\hline \multirow{2}{*}{ Total carbohydrates $(\mathrm{TCHO})^{2}$} & Leaves & 707.60 & 699.60 & 701.90 & 703.03 & 5.64 & $* * * * * * *$ \\
\hline & Stems & 833.30 & 799.80 & 847.60 & 826.90 & 3.82 & 0.08739 \\
\hline \multirow{2}{*}{ Non-fiber carbohydrates (NFC) ${ }^{2}$} & Leaves & 160.50 & 136.40 & 130.50 & 142.47 & 9.85 & $* * * * * * *$ \\
\hline & Stems & $313.00^{\mathrm{a}}$ & $150.90^{\mathrm{b}}$ & $109.40^{\mathrm{b}}$ & 191.10 & 5.94 & 0.00602 \\
\hline \multirow{2}{*}{ DM in vitro digestibility (DMIVD) ${ }^{2}$} & Leaves & $635.00^{\mathrm{b}}$ & $691.70^{\mathrm{ab}}$ & $735.00^{\mathrm{a}}$ & 687.23 & 6.67 & 0.01565 \\
\hline & Stems & $481.70^{\mathrm{ab}}$ & $514.80^{\mathrm{a}}$ & $430.00^{\mathrm{b}}$ & 475.50 & 8.44 & 0.01853 \\
\hline
\end{tabular}

${ }^{1}(\mathrm{~g} / \mathrm{kg})$ natural of matter; ${ }^{2} \mathrm{~g} / \mathrm{kg} \mathrm{DM} ;{ }^{3} \mathrm{~g} / \mathrm{kg} \mathrm{CP}$; Followed by means the same letter on the line do not differ by Tukey test (P> 0.05$)$. 
Table 3.Shrub/tree layer (leaves and stems) chemical composition and in vitro digestibility in relation to collection month

\begin{tabular}{|c|c|c|c|c|c|c|c|}
\hline Composition & Part of plant & November of 2010 & January of 2011 & February / March of 2011 & Average & $\mathrm{CV}$ & Significance \\
\hline \multirow{2}{*}{ Dry matter $(\mathrm{DM})^{1}$} & Leaves & $545.80^{\mathrm{a}}$ & $564.60^{\mathrm{a}}$ & $302.30^{\mathrm{b}}$ & 470.90 & 8.26 & 0.00000 \\
\hline & Stems & $540.50^{\mathrm{a}}$ & $563.50^{\mathrm{a}}$ & $400.80^{\mathrm{b}}$ & 501.60 & 9.31 & 0.00026 \\
\hline \multirow{2}{*}{ Organic matter $(\mathrm{OM})^{2}$} & Leaves & 909.50 & 900.00 & 899.00 & 902.83 & 1.29 & 0.32300 \\
\hline & Stems & $943.60^{\mathrm{a}}$ & $933.00^{\mathrm{b}}$ & $935.30^{\mathrm{ab}}$ & 937.30 & 0.62 & 0.03158 \\
\hline \multirow{2}{*}{ Mineral matter $(\mathrm{MM})^{2}$} & Leaves & 90.50 & 100.00 & 101.00 & 971.67 & 11.99 & 0.32300 \\
\hline & Stems & $56.40^{\mathrm{b}}$ & $67.00^{\mathrm{a}}$ & $64.70^{\mathrm{ab}}$ & 62.70 & 9.24 & 0.03158 \\
\hline \multirow{2}{*}{ Crude protein $(\mathrm{CP})^{2}$} & Leaves & 172.10 & 171.20 & 165.50 & 169.60 & 11.98 & $* * * * * * *$ \\
\hline & Stems & 72.90 & 107.70 & 89.00 & 89.87 & 33.51 & 0.22950 \\
\hline \multirow{2}{*}{ Ether extract $(\mathrm{EE})^{2}$} & Leaves & 31.60 & 38.00 & $35.00^{\mathrm{a}}$ & 34.87 & 10.48 & 0.05119 \\
\hline & Stems & $27.50^{\mathrm{a}}$ & $19.90^{\mathrm{ab}}$ & $15.60^{\mathrm{b}}$ & 21.00 & 28.92 & 0.02768 \\
\hline \multirow{2}{*}{ Neutral detergent fiber (NDF) ${ }^{2}$} & Leaves & $511.00^{\mathrm{a}}$ & $412.60^{b}$ & $522.60^{\mathrm{a}}$ & 482.07 & 6.07 & 0.00011 \\
\hline & Stems & $774.40^{\mathrm{a}}$ & $658.30^{\mathrm{b}}$ & $714.10^{\mathrm{ab}}$ & 715.60 & 8.79 & 0.03982 \\
\hline \multirow{2}{*}{ Acid detergent fiber $(\mathrm{ADF})^{2}$} & Leaves & $206.50^{b}$ & $403.10^{\mathrm{a}}$ & $463.10^{\mathrm{a}}$ & 357.57 & 17.75 & 0.00009 \\
\hline & Stems & $376.10^{\mathrm{b}}$ & $410.00^{\mathrm{b}}$ & $587.50^{\mathrm{a}}$ & 457.87 & 14.73 & 0.00069 \\
\hline \multirow{2}{*}{ Insoluble protein in neutral detergent (NDIP) ${ }^{3}$} & Leaves & 924.50 & 845.90 & 934.00 & 901.47 & 15.69 & $* * * * * * *$ \\
\hline & Stems & 793.60 & 566.10 & 557.90 & 639.20 & 40.38 & 0.29752 \\
\hline \multirow{2}{*}{ insoluble protein in acid detergent (AIP) $)^{3}$} & Leaves & 915.60 & 741.70 & 773.40 & 810.23 & 15.19 & 0.09862 \\
\hline & Stems & $865.8^{\mathrm{a}}$ & $523.3^{\mathrm{b}}$ & $676.3^{\mathrm{ab}}$ & 688.47 & 24.37 & 0.02335 \\
\hline \multirow{2}{*}{ Total carbohydrates $(\mathrm{TCHO})^{2}$} & Leaves & 705.90 & 690.80 & 698.60 & 698.43 & 4.19 & $* * * * * * *$ \\
\hline & Stems & 843.10 & 805.30 & 830.60 & 826.33 & 3.18 & 0.10833 \\
\hline \multirow{2}{*}{ Non-fiber carbohydrates (NFC) ${ }^{2}$} & Leaves & $194.90^{b}$ & $278.20^{\mathrm{a}}$ & $176.00^{\mathrm{b}}$ & 216.37 & 19.76 & 0.00599 \\
\hline & Stems & 68.70 & 147.10 & 116.60 & 110.80 & 71.89 & 0.32690 \\
\hline \multirow{2}{*}{ DM in vitro digestibility (DMIVD) ${ }^{2}$} & Leaves & 660.10 & 648.60 & 603.50 & 637.40 & 6.16 & 0.09387 \\
\hline & Stems & $397.9^{\mathrm{b}}$ & $483.7^{\mathrm{a}}$ & $444.8^{\mathrm{ab}}$ & 442.13 & 10.07 & 0.03196 \\
\hline
\end{tabular}

${ }^{1}(\mathrm{~g} / \mathrm{kg})$ natural of matter; ${ }^{2} \mathrm{~g} / \mathrm{kg} \mathrm{DM} ;{ }^{3} \mathrm{~g} / \mathrm{kg} \mathrm{CP}$; Followed by means the same letter on the line do not differ by Tukey test (P>0.05). 
Pax et K. Hoffman. CP amounts during collection months were 169.6 and 89.9 $\mathrm{g} / \mathrm{kg} \mathrm{DM}$ for leaves and stems, respectively. These results were similar for leaves and lower for stems compared to those found by Ydoyaga Santana et al. (2011), $164.7 \mathrm{~g} / \mathrm{kg} \mathrm{DM}$, Evaluating the caatinga's chemical composition in the rainy season.

Leaf NDF contents were similar between the first and third month, differing from the second month, with average results of 482.1 and $715.6 \mathrm{~g} / \mathrm{kg}$ $\mathrm{DM}$ for leaves and stems, respectively. Values were higher for leaves and lower for stems than those found by Moreira et al. (2006), $644.6 \mathrm{~g} / \mathrm{kg} \mathrm{DM}$, while assessing Caatinga forage chemical composition in the rainy season, while ADF, $516.5 \mathrm{~g} / \mathrm{kg}$ DM, was higher than that found in this study for leaves and stems, 357.6 and $457.9 \mathrm{~g} / \mathrm{kg} \mathrm{DM}$, respectively.

DM values for herbaceous and shrub/tree layer leaf and stem fractions showed no difference ( $p>0.05)$, with average values of 445.6 and 473.4 , and 470.9 and $501.6 \mathrm{~g} / \mathrm{kg} \mathrm{DM}$, respectively (Table 4). Results were similar to those found by Araújo Filho et al. (2002), with average values of $468.3 \mathrm{~g} / \mathrm{kg} \mathrm{DM}$, while assessing leaves of different Caatinga species in various growth stages.

Leaf DMIVD of both layers was considerably high. The leaf fraction had higher digestibility compared to stems, due to having fewer structural carbohydrates (NDF and ADF), increasing nutrient digestibility. Herbaceous layer showed higher DMIVD compared to the shrub/tree layer, with leaf DMIVD values of 687.2 and $637.4 \mathrm{~g} / \mathrm{kg}$ DM and stem DMIVD values of 475.5 and $442.1 \mathrm{~g} / \mathrm{kg} \mathrm{DM}$, respectively. Shrub/tree layer plants have lignified stems, reducing DM digestibility.

Taking into account forage species layer and plant structure in the rainy season, Ydoyaga Santana et al. (2011) studied cattle in Brazil's Pernambuco state semiarid and found higher leaf selection compared to stems, ranging from 41.0 to $63.8 \%$ for leaves and from 12.9 to $16.5 \%$ for stems in the herbaceous layer. In the tree/shrub layer, values from 17.3 to $33.3 \%$ for leaves and from 4.7 to $10.6 \%$ for stems were found. Differences in plant component intake may be even higher when goats are studied, as these animals are known for cutting or lopping branches, giving preference to plant leaf herbivory.

Extrusa chemical composition and DMIVD were influenced by collection months $(\mathrm{P}<0.05)$, except for NDF, ADF and NDIP (Table 5).

It is noteworthy that selectivity exerted by goats may lead to a different chemical composition from pasture. $\mathrm{DM}$ content ranged from $152.7 \mathrm{~g} / \mathrm{kg}$ $\mathrm{DM}$, in November, to $111.5 \mathrm{~g} / \mathrm{kg} \mathrm{DM}$ in the last collection month, which was associated with plant regrowth, promoting younger forage availability in the last assessment month. Younger forage was promoted by the rainfall that occurred in the last two collections, and allowed for goats to select diets with younger forage species that had high moisture content, resulting in extrusa DM reduction. Extrusa DM percentage in the evaluation periods was lower $(\mathrm{P}<$ 0.05 ) than that observed in forage samples (herbaceous and shrub/tree layers) (Table 4), which was probably due to goat selection and saliva presence in the extrusa, moistening the intake. 
Table 4. Herbaceous and shrub/tree layer (leaves and stems) chemical composition and in vitro digestibility in Caatinga

\begin{tabular}{|c|c|c|c|c|c|c|}
\hline Composition & Part of plant & Herbaceous & shrub/tree & Average & $\mathrm{CV}$ & Significance \\
\hline \multirow{2}{*}{ Dry matter $(\mathrm{DM})^{1}$} & Leaves & 445.60 & 470.90 & 458.25 & 25.86 & $* * * * * * *$ \\
\hline & Stems & 473.40 & 501.60 & 487.50 & 19.8 & $* * * * * * *$ \\
\hline \multirow{2}{*}{ Organic matter $(\mathrm{OM})^{2}$} & Leaves & 906.30 & 902.80 & 904.55 & 1.59 & $* * * * * * *$ \\
\hline & Stems & $924.30^{\mathrm{b}}$ & $937.30^{\mathrm{a}}$ & 930.80 & 1.47 & 0.01470 \\
\hline \multirow{2}{*}{ Mineral matter $(\mathrm{MM})^{2}$} & Leaves & 93.70 & 97.20 & 95.45 & 15.09 & $* * * * * * *$ \\
\hline & Stems & $75.70^{\mathrm{a}}$ & $62.70^{\mathrm{b}}$ & 69.20 & 19.77 & 0.01470 \\
\hline \multirow{2}{*}{ Crude protein $(\mathrm{CP})^{2}$} & Leaves & 162.50 & 169.60 & 166.05 & 24.04 & 0.30974 \\
\hline & Stems & 77.20 & 89.90 & 83.55 & 30.59 & 0.18614 \\
\hline \multirow{2}{*}{ Ether extract $(\mathrm{EE})^{2}$} & Leaves & 40.80 & 34.80 & 37.80 & 23.34 & 0.07717 \\
\hline & Stems & 20.20 & 21.00 & 20.60 & 32.57 & $* * * * * * *$ \\
\hline \multirow{2}{*}{ Neutral detergent fiber (NDF) ${ }^{2}$} & Leaves & $560.60^{\mathrm{a}}$ & $482.10^{\mathrm{b}}$ & 521.35 & 10.08 & 0.00032 \\
\hline & Stems & $635.80^{\mathrm{b}}$ & $715.60^{\mathrm{a}}$ & 675.70 & 15.7 & 0.04880 \\
\hline \multirow{2}{*}{ Acid detergent fiber $(\mathrm{ADF})^{2}$} & Leaves & $322.40^{\mathrm{b}}$ & $357.60^{\mathrm{a}}$ & 340.00 & 33.23 & 0.00786 \\
\hline & Stems & $523.00^{\mathrm{a}}$ & $457.90^{\mathrm{b}}$ & 490.45 & 29.64 & 0.00170 \\
\hline \multirow{2}{*}{ Insoluble protein in neutral detergent (NDIP) ${ }^{3}$} & Leaves & 820.00 & 901.40 & 860.70 & 23.29 & 0.27525 \\
\hline & Stems & 512.50 & 639.20 & 575.85 & 37.99 & 0.12391 \\
\hline \multirow{2}{*}{ Insoluble protein in acid detergent $(\mathrm{AIP})^{3}$} & Leaves & $533.20^{\mathrm{b}}$ & $810.30^{\mathrm{a}}$ & 671.75 & 39.86 & 0.00841 \\
\hline & Stems & 688.50 & 587.10 & 637.80 & 38.73 & 0.27056 \\
\hline \multirow{2}{*}{ Total carbohydrates $(\mathrm{TCHO})^{2}$} & Leaves & 703.00 & 698.40 & 700.70 & 4.66 & $* * * * * * *$ \\
\hline & Stems & 826.90 & 826.40 & 826.65 & 3.96 & $* * * * * * *$ \\
\hline \multirow{2}{*}{ Non-fiber carbohydrates $(\mathrm{NFC})^{2}$} & Leaves & $142.50^{\mathrm{b}}$ & $216.40^{\mathrm{a}}$ & 179.45 & 7.83 & 0.00238 \\
\hline & Stems & $191.10^{\mathrm{a}}$ & $110.80^{b}$ & 150.95 & 5.92 & 0.04054 \\
\hline \multirow{2}{*}{ DM in vitro digestibility (DMIVD) ${ }^{2}$} & Leaves & $687.20^{\mathrm{a}}$ & $637.40^{\mathrm{b}}$ & 662.30 & 7.83 & 0.01508 \\
\hline & Stems & 475.50 & 442.10 & 458.80 & 5.92 & 0.09746 \\
\hline
\end{tabular}

${ }^{1}(\mathrm{~g} / \mathrm{kg})$ natural of matter; ${ }^{2} \mathrm{~g} / \mathrm{kg} \mathrm{DM} ;{ }^{3} \mathrm{~g} / \mathrm{kg} \mathrm{CP}$; Followed by means the same letter on the line do not differ by Tukey test (P> 0.05$)$ 
Table 5. Extrusa chemical composition of goats raised in Caatinga pasture in relation to collection month

\begin{tabular}{|c|c|c|c|c|c|c|}
\hline Composition & November of 2010 & January of 2011 & February / March of 2011 & Average & $\mathrm{CV}$ & Significance \\
\hline Dry matter $(\mathrm{DM})^{1}$ & $152.70^{\mathrm{a}}$ & $142.10^{\mathrm{a}}$ & $111.50^{\mathrm{b}}$ & 135.43 & 13.73 & 0.00002 \\
\hline Organic matter $(\mathrm{OM})^{2}$ & $877.10^{\mathrm{a}}$ & $856.80^{\mathrm{b}}$ & $855.20^{\mathrm{b}}$ & 863.03 & 2.00 & 0.00618 \\
\hline Mineral matter $(\mathrm{MM})^{2}$ & $122.90^{\mathrm{b}}$ & $143.20^{\mathrm{a}}$ & $144.80^{\mathrm{a}}$ & 136.97 & 12.62 & 0.00618 \\
\hline Crude protein $(\mathrm{CP})^{2}$ & $141.90^{\mathrm{b}}$ & $146.80^{\mathrm{ab}}$ & $170.05^{\mathrm{a}}$ & 152.92 & 15.94 & 0.01580 \\
\hline Ether extract $(\mathrm{EE})^{2}$ & $38.10^{\mathrm{a}}$ & $34.40^{\mathrm{ab}}$ & $28.30^{\mathrm{b}}$ & 33.60 & 22.21 & 0.01003 \\
\hline Neutral detergent fiber (NDF) ${ }^{2}$ & 598.60 & 633.20 & 619.40 & 617.07 & 8.09 & 0.24513 \\
\hline Acid detergent fiber $(\mathrm{ADF})^{2}$ & 449.20 & 517.80 & 503.60 & 490.20 & 14.85 & 0.06531 \\
\hline Insoluble protein in neutral detergent (NDIP) ${ }^{3}$ & 910.4 & 799.60 & 843.30 & 851.10 & 16.79 & 0.17664 \\
\hline insoluble protein in acid detergent $(\mathrm{AIP})^{3}$ & $94.2^{\mathrm{b}}$ & $156.00^{\mathrm{a}}$ & $172.00^{\mathrm{a}}$ & 140.73 & 21.03 & 0.00722 \\
\hline Total carbohydrates $(\mathrm{TCHO})^{2}$ & $697.00^{\mathrm{a}}$ & $675.70^{\mathrm{ab}}$ & $656.40^{\mathrm{b}}$ & 676.37 & 4.60 & 0.01147 \\
\hline Non-fiber carbohydrates $(\mathrm{NFC})^{2}$ & $98.50^{\mathrm{a}}$ & $42.50^{\mathrm{b}}$ & $37.00^{\mathrm{b}}$ & 59.33 & 70.80 & 0.00159 \\
\hline DM in vitro digestibility (DMIVD) ${ }^{2}$ & $514.1^{\mathrm{b}}$ & $593.00^{\mathrm{a}}$ & $553.3^{\mathrm{ab}}$ & 553.47 & 11.74 & 0.01986 \\
\hline
\end{tabular}

${ }^{1}(\mathrm{~g} / \mathrm{kg})$ natural of matter; ${ }^{2} \mathrm{~g} / \mathrm{kg} \mathrm{DM} ;{ }^{3} \mathrm{~g} / \mathrm{kg} \mathrm{CP}$; Followed by means the same letter on the line do not differ by Tukey test (P>0.05). 
CP content variation only occurred between samples taken in November 2010 and February/March 2011, probably due to lack of rain in the first evaluation month and rainfall occurrence in the following months (Figure 1), increasing extrusa $\mathrm{CP}$ content. Average crude protein content was $153.10 \mathrm{~g} / \mathrm{kg} \mathrm{DM}$, lower than the result found by Pfister (1983), 192.00 $\mathrm{g} / \mathrm{kg} \mathrm{DM}$, for goats in Caatinga during the rainy season. Santos et al. (2009), while studying fistulated sheep in the same experimental area, found results below those of this study, possibly due to goat selectivity during grazing, having a diet with higher protein content in relation to sheep

According to Goetsch et al. (2010), several factors may influence forage selection, with concentrate supplementation among them, allowing for higher or lower diet selection, according to genotype. Results found in this study indicate that animals were able to select forage as to keep extrusa $\mathrm{CP}$ above the minimum required for rumen microorganism growth. Casey \& Van Niekerk (1988) pointed a diet CP content of less than $60 \mathrm{~g} / \mathrm{kg} \mathrm{DM}$ as a considerable reducing factor for Boer goat voluntary intake. According to Poppi \& McLennan (1995), a minimum percentage of $70 \mathrm{~g} / \mathrm{kg} \mathrm{DM}$ is required for proper microorganism activity in the rumen, in order to use forage fiber components ingested. In addition, the authors stated that lower levels would cause forage intake decrease, reflecting in lower performance. Despite the high crude protein level found in goat extrusa, studies that qualify this protein, involving fractionation evaluations that may allow for elucidating its availability, are needed.

Both herbaceous and shrub/tree layers, as well as extrusa, showed low in vitro DM digestibility rates. Caatinga includes forages that can reach $\mathrm{CP}$ contents higher than $200 \mathrm{~g} / \mathrm{kg}$ DM. However, Caatinga forage digestibility is usually low (ARAÚJO FILHO et al., 2002; SANTOS et al., 2010), as native Caatinga forages often have high tannin contents. Moreover, fiber and lignin content increase during the dry period. Low forage digestibility has always been associated with high lignin content. CP content may not be a limiting factor in Caatinga, but the likely high tannin and lignin content presence on forage and its low digestibility, associated with a significant AIP percentage, could make $\mathrm{CP}$ a limiting nutrient for animal performance in rainy season.

NDF and ADF contents were the same throughout the experiment, showing that, although Caatinga vegetation is very dynamic and undergoes constant chemical composition changes during short time periods, goat extrusa during grazing remained the same, without NDF and ADF content changes.

Araújo Filho et al. (2002) studied Caatinga deciduous woody species phenology and nutritional value, which are considered important for ruminant diets, and found chemical composition and in vitro digestibility variations throughout the phenological cycle. The best results were achieved during full vegetation, which also coincided with increased biomass availability. Corroborating this statement, Vasconcelos et al. (1996) observed pasture crude protein content decrease during transition from rainy to dry season, while the opposite behavior was observed for NDF and lignin concentrations.

However, DMIVD values in this study ranged from 51.41 to $59.30 \mathrm{~g} / \mathrm{kg} \mathrm{DM}$ and were higher than $460 \mathrm{~g} / \mathrm{kg} \mathrm{DM}$, which was found by Marques et al. (2014) while studying a Caatinga area 
from Cariri region, Paraíba state. Variations may be associated with ripeness degree, plant collection period and rainfall influence on DMIVD, leading to $\mathrm{CP}$ reduction and lignin increase, which contributed to maximize neutral detergent and acid fiber content, reducing digestibility (SOUZA et al., 2013).

Caatinga herbaceous and shrub/tree layers had similar chemical compositions throughout the experiment, except for herbaceous layer leaf DMIVD, which was higher than shrub/tree layer leaf DMIVD, with values of 687.0 and $637.4 \mathrm{~g} / \mathrm{kg} \mathrm{DM}$, respectively.

Changes in rainfall of rainy season in the caatinga altered pasture quality, causing changes in the diet selected by goats, mainly in DM, CP, NDF and DMIVD.

\section{REFERENCES}

ARAÚJO FILHO, J.A.; CRISPIM, M.A. Pastoreio combinado de bovinos, caprinos e ovinos em áreas de caatinga no Nordeste do Brasil. In:

CONFERÊNCIA VIRTUAL GLOBAL SOBRE PRODUÇÃO ORGÂNICA DE BOVINOS DE CORTE, 2002,

Concórdia, SC. Anais... Concórdia, SC

/ Corumbá, MS: Universidade do

Contestado / Embrapa Pantanal, 2002. p.1-7.

ARAUJO FILHO, J.A.; CARVALHO, F.C.; SILVA, N.L. Fenología y valor nutritivo de follajes de algunas especies forrajeras de La Caatinga.

Agroforestería en las Américas, v.9, n.33-34, p.33- 37, 2002.
ASSOCIATION OF OFFICIAL ANALYTICAL CHEMISTS - AOAC. Official methods of analysis. 15.ed. Washington, 1990.

ASSOCIATION OF OFFICIAL ANALYTICAL CHEMISTS - AOAC. Official methods of analysis. 16.ed. Washington, 1995.

CASEY, N.H.; Van NIEKERK, W.A. The Boer goat. I. Origin, adaptability, performance testing, reproduction and milk production. Small Ruminant Research, v.13, n.01. p 291-302, 1988.

DRUMOND, M.A.A.; SALVIANO, L.M.C.; CAVALCANTI, N.B. Produção, distribuição da biomassa e composição bromatológica da parte aérea da faveleira. Revista Brasileira de Ciências Agrárias, v.2, n.4, p.308310, 2007.

FERREIRA, M.A.; SILVA, F.M.; BISPO, S.V.; AZEVEDO, M. Estratégias na suplementação de vacas leiteiras no semi-árido do Brasil. Revista Brasileira de Zootecnia, v.38, p.322-329, 2009.Supl. especial.

FORMIGA, L.D.A.S.; PEREIRA FILHO, J.M.; OLIVEIRA, N.S.; SILVA, A.M.A.; CÉZAR, M.F.; SOARES, D.C. Valor nutritivo da vegetação herbácea de caatinga enriquecida e pastejada por ovinos e caprinos. Revista Brasileira de Saúde e Produção Animal [online], v.12, n.2, p.403-415, 2011.

GOETSCH, A.; GIPSON, T.A.; ASKAR, A.R. PUCHALA, R Invited review: Feeding behavior of goats. Journal of animal science, v.88, n.1, p.361-373, 2010. 
HOLDEN, L.A. Comparison of methods of in vitro dry matter digestibility for ten feeds. Journal Dairy Science, v.82, n.8, p.1791-1794, 1999.

MARQUES, C.A.T.; MEDEIROS, A.N.D.; COSTA, R.G.; CARVALHO, F.F.R.; ARAÚJO, M.J.; TORREÃO, J.N.C. Performance and carcass traits of Moxotó growing goats supplemented on native pasture under semiarid conditions.

Revista Brasileira de Zootecnia, v.43, n.3, p.151-159, 2014.

MERTENS, D.R. Creating a system for meeting the fiber requirements of dairy cows. Journal of Dairy Science, v.80, n.7, p.1463-1481, 1997.

MOREIRA, J.N.; LIRA, M.A.; SANTOS, M.V.F.; FERREIRA, M.A.; ARAÚJO, G.G.L.; FERREIRA, R.L.C.; SILVA, G.C. Caracterização da vegetação de caatinga e da dieta de novilhos no sertão de Pernambuco.

Pesquisa Agropecuária Brasileira, v.41, n.11, p.1643-1651, 2006.

PFISTER, J.A. Nutrition and feeding behaviour of goat and sheep grazing deciduous shrub wodland in Northeastern Brazil. 1983. 130p, Ph.D. (Thesis) - Utah State University, Logan.

POPPI, D.P.; McLENNAN, S.R. Protein and energy utilization by ruminants at pasture. Journal of Animal Science, v.73, n.1, p.278-290, 1995.

SANTOS, G.R.A.; BATISTA, A.M.V.; GUIM, A.; SANTOS, M.V.F.; MATOS, D.S.; SANTORO, K.R. Composição química e degradabilidade in situ da ração em ovinos em área de caatinga no sertão de Pernambuco. Revista Brasileira de Zootecnia, v.38, p.384-391, 2009.
SANTOS, M.V.F.; LIRA, M.; DUBEUX JUNIOR, J.C.B. GUIM, A.; MELLO, A.C.L.; CUNHA, M.V. Potential of Caatinga forage plants in ruminant feeding. Revista Brasileira de Zootecnia, v.39, p.204-215, 2010. Ssupl. especial.

SNIFFEN, C.J.; O'CONNOR, J.D.; VAN SOEST, P.J.; FOX, D.G.; RUSSELL, JB. A net carbohidrate and protein system for evaluating cattle diets: II. Carbohydrate and protein availability. Journal of Animal Science, v.70, p.35623577,1992 .

SOUZA, C.; BARRETO, H.F.; GURGEL, V.; COSTA, F.

Disponibilidade e valor nutritivo da vegetação de caatinga no semiárido norte Riograndense do Brasil. Holos, v.3, p.196-204, 2013.

TILLEY, J.M., TERRY, R.A. A two stage technique for the in vitro digestion of forage crops. Journal of the British Grassland Society, v.18, n.2, p.104-111, 1963.

VAN SOEST, P.J. Nutritional ecology of the ruminant. New York: Cornell University Press, 1994. 476p.

VAN SOEST, P.J.; ROBERTSON, J.B.; LEWIS, B.A. Methods for dietary fiber, neutral detergent fiber, and nonstarch polysaccharides in relation to animal nutrition. Journal of Dairy Science, v.74, n.10, p.3583-3597, 1991.

VASCONCELOS, M.A.B.; OLIVEIRA, E.R.; FERNANDES, F.D.; BARROS, N.N. Composição química da dieta de caprinos no semiarido do Estado do Ceará. In: REUNIÃO ANUAL DA SOCIEDADE BRASILEIRA DE ZOOTECNIA, 33, 1996, Fortaleza. Anais... Fortaleza: Sociedade Brasileira de Zootecnia, 1996. p.265-266. 
YDOYAGA SANTANA, D.F.; LIRA, M.A.; SANTOS, M.V.F.; FERREIRA, M.A. SILVA, M.J.A.; MARQUES, K.A.; MELLO, A.C.L.; SANTOS, D.C. Caracterização da caatinga e da dieta de novilhos fistulados, na época chuvosa, no semiárido de Pernambuco. Revista Brasileira de Zootecnia, v.40, n.1, p.69-78, 2011.

UNIVERSIDADE FEDERAL DE VIÇOSA - UFV. SAEG: Sistema para Análises Estatísticas. Versão 9.1.

Viçosa, MG: Fundação Arthur

Bernardes, 2007.

Data de recebimento: $25 / 08 / 2016$

Data de aprovação: 03/08/2017 